\title{
Undergraduate Entrepreneurship Education: The Pros and Cons for the Nigerian Context [A 10-Year (2008 vs. 2018) Gap Comparative Case Study of Federal Polytechnic Ede, Nigeria]
}

\author{
Choice, Oluwafolahan Honour Candour \\ Department of Business Administration and Management, Federal Polytechnic, Ede, Nigeria
}

\begin{abstract}
In year 2000, the Federal Government of Nigeria (FGN) and United Nations Educational Scientific and Cultural Organization (UNESCO) partnered to revitalize Technical and Vocational Education (TVE) curricula resulting in the full incorporation of Entrepreneurship Education (EEd) into TVE curricula. Correspondingly, FGN introduced EEd into university undergraduate curriculum in 2006. Whether EEd has achieved the desired outcomes for undergraduates and Nigeria without obstacles and challenges remained a recurring question. This study examined the pros and cons of Undergraduate EEd in the light of a decade (2008 vs. 2018) gap comparative case study of Federal Polytechnic, Ede, Nigeria. The baseline objectives were to: identify the benefits of EEd to the undergraduates; identify the obstacles mitigating the use of knowledge and skills inculcated; examine the challenges of implementing the curricula; determine the relevance of the programme to the nation; and to investigate if EEd should continue. Corollary objective compared results for the years. The study utilized primary and secondary data. Purposeful stratified random samples were 80 for 2008 and 350 for 2018. Simple percentages, frequencies and differentials were used for analysis. Key findings revealed empowerment for self-employment and acquisition of entrepreneurial knowledge as prime benefits of EEd while the consistent obstacle to using the knowledge and skills acquired was finance/lack of seed capital. Major challenge in implementing the curricula was inadequate infrastructures in 2008 and inadequate government funding in 2018. Respondents deemed that EEd should subsist. The study concluded that government and stakeholders should support EEd policies and implementation through adequate funding and requisite infrastructures.
\end{abstract}

Key Words: Entrepreneurship; Entrepreneurship Education; Curriculum, Tertiary Institutions, Undergraduates

\section{INTRODUCTION AND BACKGROUND}

Tn the first decade of the current millennium i.e. 2001 to 2010, very few studies were conducted as per Entrepreneurship Education (EEd) in Nigerias tertiary institutions. Justifiably or so, it was because of the nascent introduction EEd began to have in the nations ivory towers then. Agbonlahor (2016) posited that EEd courses were introduced to undergraduate curriculum of universities in Nigeria in the second half of the first decade, precisely in 2006. The United Nations Educational Scientific and Cultural
Organization (UNESCO) and Federal Government of Nigeria (FGN) pact of reviewing and updating the Nigerias Technical and Vocational Education (TVE) curricula had its first phase between 2001 and August 2007. The outcome of which the National Board for Technical Education (NBTE) asserted that Information and Communication Technology (ICT) and EEd had been fully incorporated into all TVE curricula. Choice (2008) adduced that tertiary institutions were witnessing a new dawn just as ICT and EEd were being fully incorporated into the curricula of TVE in Nigeria of which Polytechnics belong and were a major beneficiary. Clearly so, few studies on undergraduate Entrepreneurship Education such as that of Choice (2008), Aladekomo (2004) where conducted during that period of the first decade.

The second decade of the millennium i.e. 2011 till date, has witnessed an avalanche of research studies in the direction of undergraduate Entrepreneurship Education (EEd) in Nigeria and as per the Nigerian context. This is justifiably so as a result of the full incorporation and full implementation of EEd curricula in the countrys tertiary institutions. However, most of these research efforts had had single period focus in the selected universities, polytechnics or other tertiary institutions used as case studies. The research gap that remained largely unattended to have been periodic comparative case studies which could bring to fore the consistency or otherwise that might reveal the contrasts of factors of the pros and the cons of the millennial introduction of Entrepreneurship Education in Nigerias tertiary institutions.

Hinging on this obvious research gap was why this research exercise sought to attempt a comparative study of the pros and the cons of Undergraduate Entrepreneurship Education in the Nigerian context using the baseline objectives in the pioneer efforts of Choice (2008). Therefore, the specific purpose of this study was to comparatively:

1. Identify the benefits of Entrepreneurship Education to the undergraduates in the periods under review;

2. Identify the obstacles to using the knowledge and skills acquired from EEd during/at the end of the recipients programme; 
3. Highlight the challenges of implementing the curricula on Entrepreneurship Education;

4. Determine the relevance of Entrepreneurship Education to the Nigerian nation;

5. Ascertain if the recipients wanted EEd unit based courses to continue being run; and

6. Contrast the results of objectives "a" to "e".

\section{LITERATURE REVIEW}

\subsection{The Concept of Entrepreneurship Education}

Olokundun (2017) defined Entrepreneurship Education as any programme or process of education targeted at motivating entrepreneurial actions and behaviour. Entrepreneurship education may be described as scope of lectures, curricula and programmes that attempt to provide students with the necessary entrepreneurial competencies, knowledge and skills, geared towards the pursuit of a career in entrepreneurship (Oduwaiye, 2009; Ooi, Selvarajah and Meyer, 2011; and Olokundun, 2017). The definition of Olokundun (2017) supports Choice (2008) that entrepreneurship education is the education which aims at directly stimulating entrepreneurship.

The European Commission (EC) (2011) posited a broader definition of Entrepreneurship Education as a process by which learners are equipped with a wide set of competencies that can bring about greater individual, social and economic benefits since the ability gained can be applied in any aspects of peoples lives. Okoli and Allahna (2014) leaned towards ECs broader definition with their position that EEd is the type of education fashioned out to prepare learners for innovative ventures which lead to self reliance and economic emancipation.

By and large Entrepreneurship Education furnishes the recipients with the knowledge, skills, aptitudes and motivation to encourage enterprise success at various spheres or settings in life.

\subsection{Objectives of Entrepreneurship Education}

The global classic and most commonly cited objectives of Entrepreneurship Education are those catalogued by Garavan and OCinneide (1994). These are:

1. To acquire knowledge germane to entrepreneurship;

2. To acquire skills in the use of techniques in the analyses of business situations and in the synthesis of action plans;

3. To identify and stimulate entrepreneurship drive, talent and skills;

4. To undo the risk averse bias of many analytical techniques;

5. To develop empathy and support for all unique aspects of entrepreneurship;

6. To devise attitudes towards change; and

7. To encourage new start-ups and other entrepreneurship ventures.
In Nigeria, three main objectives of EED in the Polytechnics according to National Board for Technical Education (NBTE) (2004) are:

1. To create general entrepreneurship awareness in the student with a view to inculcating in him the spirit of self-reliance;

2. To equip the student with necessary entrepreneurial skills for self-employment of management; and

3. To create awareness in a student and motivate him towards self-employment through the development of personal skills, competencies effectiveness and aptitudes using project based work in an economic setting to set-up and manage a small and medium enterprises successful.

\subsection{Prospects of Entrepreneurship Education for the} Undergraduates and the Nation

Ample benefits abound that EEd accords the individual recipient and his society. United Nations Industrial Development Organization (UNIDO) (2012) posited that entrepreneurship has the proclivity to power up the Nigerian economy, and statistics has unveiled that there are over 17 million business enterprises employing over 31 million Nigerians. Therefore, an education in the direction of Entrepreneurship is regarded as the most important instrument of a fundamental change towards the achievement of economic goals such as economic development, job creation and poverty eradication, especially in the Nigerian context (Okoli, 2011; Agi and Yellowe, 2013; and Olokundun, 2017)

The National Economic Empowerment and Development Strategy (NEEDS) (2004) lends credence to the place and role of education in the development of self reliant abilities and entrepreneurship skills in individuals. Hence, the role of EEd in the empowerment of individuals and the development of the Nigerian nation or any nation for that matter cannot be overemphasized.

\subsubsection{Prospects of Entrepreneurship Education for the Undergraduates}

Choice (2008), Barker (2007) and selected views highlighted the Prospects of Entrepreneurship Education for the individuals, in this case, the undergraduates. These prospects stem from the characteristics that are learned, acquired and/or developed through EEd. They are amongst others:

1. Motivation i.e. enthusiastic visions- the driving force of an enterprise

2. Encouragement and development of personal responsibilities

3. Empowerment for prudent risk taking through assessment of costs and market/consumer needs

4. Development of positive thinking mentality and decision-making abilities

5. Opportunities for enormous financial gain through the operation of the entrepreneurial ventures i.e. creation of wealth for the individual 
6. Job satisfaction and flexibility of work via selfemployment

7. Ability to have great accomplishment and selfactualization

8. Self-sufficiency and self-reliance

9. Opportunity for personal/individual contribution to the national economy or collective society

In all, EEd for the individual/undergraduate will lead to the development of basic awareness of the contribution which enterprises make to the economic system of his/her nation, improvement of personal qualities and building of attitudes necessary for adjustment to personal and employment situations.

\subsubsection{Prospects of Entrepreneurship Education for a National Economy like Nigeria}

For a developing national economy, in this case, Nigeria, which require better leverage for global competiveness, Arowomole and Oyedokun (2006), Barker (2007), Choice (2008), and other selected views advance the following as prospects of Entrepreneurship Education:

1. Developments of new markets

2. Discovery of sources of materials

3. Mobilization of capital resources

4. Introduction of new technologies

5. Creation/generation of employment

6. Creation, provision and improvement of/on goods, services and technology

7. Increased/Increasing productivity

8. Stimulation of continuous evolution, growth and development of the economy

9. Proper utilization of human potentiality and natural resources

10. Development of indigenous small (and medium) enterprises

11. Eradication of regional imbalances through even development

12. Higher per capital income etc.

\subsection{Nigerias Educational Policy, Entrepreneurship Education and Tertiary Education}

Akinyemi (1987) argued that educational policies in Nigeria for colonial and post-colonial eras up till the 1970s were devoid of EEd. Aladekomo (2004) supporting Visser (1997) equally argued that the 1980 s policy options for tertiary education had serious orientations for science and technology and absolutely none for self-employment. The concern for entrepreneurship in the 1981 National Educational Policy (NEP) was very negligible as emphasis on technical skills acquisition was for the purpose of gaining paid employmentsection 6 of the 1981 NEP (Aladekomo, 2004). National Directorate of Employment (NDE) was targeted at out-ofschool youth while education curriculum for in-school youth remained silent... (Aladekomo, 2004).
In the 1990s, only very few undergraduate programmes had EED incorporated into the curricula such as Business Administration and Management in the Polytechnics. In the 2000s, however, a major breakthrough came for EEd in Nigerias educational policy with the FGN-UNESCO pact for revitalization of TVE curricula. Hence ICT and EED were fully incorporated into the TVE of which the countrys Polytechnics benefitted from. Subsequently, Nigerias Federal Government introduced EEd into the nations universities undergraduate curriculum in 2006 (Okojie, 2009; and Agbonlahor, 2016).

These steps by the FGN in the 2000s is in tandem with the United Nations Development Programme (UNDP) (2011) and Igbuzor (2013) positions that education is fundamental to entrepreneurship development, because empowering people with education (in this context EEd) can amplify the possibilities for job creation.

\subsection{Obstacles and Challenges facing Undergraduate} Entrepreneurship Education in Nigeria

The implementation of the EEd curricula in the nations tertiary institutions is hampered by many challenges. Even as the students are taught notwithstanding the daunting challenges, various obstacles still manifest that hinder the effective and efficient utilization of entrepreneurial/business knowledge and skills acquired in their training. A couple of these have been identified by various scholars and authorities such as Agbonlahor (2016); Maina (2014); The Consortium for Entrepreneurship Education (2012); Zhou and Haixia (2012); Adiele (2010); Choice (2008); Awoyemi, Ayobami, Azeez and Daniel (2005); Adegoke (2003); and Garavan and OCinneide (1994).

A key argument of Garavan and OCinneide (1994) is that EEd are frequently of short duration compared to other educational programmes concerned with helping people embark on a major career. Other scholars and authorities cited above identified and highlighted obstacles and challenges facing Entrepreneurship Education to include among others the following:

1. Inadequate government funding

2. Inadequate infrastructural facilities

3. Inadequate qualified teaching staff

4. Inadequate instructional materials/equipment

5. Absence of practical classes, model office and shops etc.

6. Poor attitude of students to their studies

7. Nonchalant attitude of some teachers - lecturers and instructors, to their duties

8. Finance e.g. Lack of seed capital

9. Stringent government policies and legal/regulatory constraints touching entrepreneurship

10. Sociological influences such as stigma attached to small business ownership and/or low self esteem

11. Inadequate and incompetent manpower

12. Lack of market familiarity 
13. Inadequate and/or poor infrastructures e.g. Electric power generation/distribution; transport/communication networks

14. Influence/competition from foreign entrepreneurs

15. Lack of technical skills

16. Opportunities for paid employment especially in blue chip firms

17. Governments lack of policy coherence

18. Unstable macro-economic environment

19. Poor implementation and coordination of efforts on SMEs

20. Absence of sustainable institutional mechanisms

21. Lack of effective financial systems

22. Overemphasis on theory delivery

23. Absence of research support and linkages

24. Absence of curricula capacity to support the training etc.

\section{RESEARCH METHODOLOGY}

This work is essentially a blend of basic research and evaluative case study of a contemporary issue. The study utilized primary data obtained from survey of the case study while secondary data were sourced from the past dissertation/theses, analysis of views, comments and opinions in books, journals, magazines and newspapers, internet materials as well as speeches and addresses in seminars, conferences and workshops. Purposeful stratified random samples were 80 for 2008 and 350 for 2018. Quantitative methods such as simple percentages, frequencies and differentials were employed in analysis and presentation of data/information collected.

\section{TABULATED RESULTS AND CONCISE DISCUSSIONS}

Table 4.1Respondents Demographic Distribution

\begin{tabular}{|c|c|c|c|c|c|c|c|}
\hline & \multicolumn{3}{|c|}{2008} & \multicolumn{3}{|c|}{2018} & \\
\hline Sex & Frequency & Percentage & Rank & Frequency & Percentage & Rank & Difference \\
\hline Male & 47 & 58.75 & $1^{\mathrm{st}}$ & 213 & 64.74 & $1^{\text {st }}$ & 5.99 \\
\hline Female & 33 & 41.25 & $2^{\text {nd }}$ & 107 & 32.52 & $2^{\text {nd }}$ & -8.73 \\
\hline Not Indicated & 0 & 0.00 & $3^{\text {rd }}$ & 9 & 2.74 & $3^{\text {rd }}$ & -2.74 \\
\hline Total & 80 & 100.00 & & 329 & 100.00 & & \\
\hline Age (in years) & Frequency & Percentage & Rank & Frequency & Percentage & Rank & Difference \\
\hline $16-20$ & 6 & 7.5 & $3^{\text {rd }}$ & 40 & 12.16 & $3^{\text {rd }}$ & 4.66 \\
\hline $21-25$ & 47 & 58.75 & $1^{\mathrm{st}}$ & 195 & 59.27 & $1^{\text {st }}$ & 0.52 \\
\hline $26-30$ & 27 & 33.75 & $2^{\text {nd }}$ & 86 & 26.14 & $2^{\text {nd }}$ & -7.61 \\
\hline$\geq 30$ & 0 & 00.00 & $4^{\text {th }}$ & 3 & 0.91 & $5^{\text {th }}$ & 0.91 \\
\hline Not Indicated & 0 & 00.00 & $4^{\text {th }}$ & 5 & 1.52 & $4^{\text {th }}$ & 1.52 \\
\hline Total & 80 & 100.00 & & 329 & 100.00 & & \\
\hline Marital Status & Frequency & Percentage & Rank & Frequency & Percentage & Rank & Difference \\
\hline Single & N/A & N/A & & 300 & 91.18 & $1^{\text {st }}$ & N/A \\
\hline Married & N/A & N/A & & 12 & 3.65 & $3^{\text {rd }}$ & N/A \\
\hline Not Indicated & N/A & N/A & & 17 & 5.17 & $2^{\text {nd }}$ & N/A \\
\hline Total & N/A & N/A & & 329 & 100.00 & & N/A \\
\hline Faculty & Frequency & Percentage & Rank & Frequency & Percentage & Rank & Difference \\
\hline Applied Science & 20 & 25.00 & $1^{\mathrm{st}}$ & 77 & 23.40 & $2^{\text {nd }}$ & -1.60 \\
\hline Business Studies & 20 & 25.00 & $1^{\text {st }}$ & 141 & 42.86 & $1^{\text {st }}$ & 17.86 \\
\hline Engineering Technology & 20 & 25.00 & $1^{\mathrm{st}}$ & 52 & 15.81 & $4^{\text {th }}$ & -9.19 \\
\hline Environmental Studies & 20 & 25.00 & $1^{\mathrm{st}}$ & 56 & 17.02 & $3^{\text {rd }}$ & -7.98 \\
\hline Not Indicated & 0 & 0 & $5^{\text {th }}$ & 3 & 0.91 & $5^{\text {th }}$ & 0.91 \\
\hline Total & 80 & 100.00 & & 329 & 100.00 & & \\
\hline Level & Frequency & Percentage & Rank & Frequency & Percentage & Rank & Difference \\
\hline HND ( \& 5 Returning HND) & 54 & 67.50 & $1^{\text {st }}$ & 180 & 54.71 & $1^{\text {st }}$ & -12.79 \\
\hline ND $(\& \sim 8$ Returning ND) & 26 & 32.50 & $2^{\text {nd }}$ & 140 & 42.55 & $2^{\text {nd }}$ & -10.05 \\
\hline Not Indicated & 0 & 00.00 & $3^{\text {rd }}$ & 9 & 2.74 & $3^{\text {rd }}$ & 2.74 \\
\hline Total & 80 & 100 & & 329 & 100.00 & & \\
\hline
\end{tabular}

Source: Choice (2008); Field Survey Result (2018) 
It is noted from Table 4.1 that retrieval/response rate in 2008 was $100 \%$ (i.e. 80 out of 80 ) while 2018 is 94 percent (i.e. 329 out of 350). This difference of $6 \%$ may be attributed to the size of sample for each year. Table 4.1 also signifies that majority of the respondents were male for the comparative years. Approximately $60 \%$ of the respondents for the comparative years fall in the age range 21-25 while an average of $30 \%$ belong to age $26-30$ years. The remaining $10 \%$ thereabouts are either 20 years and below or 30 years and above. The implication is a very youthful undergraduate population in the prime of their youth and on the verge of launching into career horizon. While the sample was evenly distributed across faculties for the 2008 base year at $25 \%$ each, the comparative year 2018 recorded highest response of $42.86 \%$ from the School of Business Studies followed by $\sim 23 \%, \sim 17 \%$ and $\sim 16 \%$ for Applied Sciences, Environmental Studies and Engineering Technology respectively. Higher National Diploma (HND) respondents were in the majority of $\sim 68 \%$ and $\sim 55 \%$ for the years, on the other hand National Diploma (ND) respondents were in the minority. This implies a well-informed set of respondents.

Table 4.2.1Responses on whether Entrepreneurship Education is beneficial to Undergraduates in Nigeria or not

\begin{tabular}{|c|c|c|c|c|c|c|c|}
\hline \multicolumn{2}{|c|}{$\mathbf{2 0 0 8}$} & \multicolumn{3}{|c|}{$\mathbf{2 0 1 8}$} \\
\hline General Response & Frequency & Percentage & Rank & Frequency & Percentage & Rank & Difference \\
\hline Yes & 80 & 100.00 & $1^{\text {st }}$ & 313 & 95.14 & $1^{\text {st }}$ & -4.86 \\
\hline No & 0 & 0 & $2^{\text {nd }}$ & 8 & 2.43 & $2^{\text {nd }}$ & 2.43 \\
\hline Not Indicated & - & - & & 8 & 2.43 & $2^{\text {nd }}$ & 2.43 \\
\hline Total & 80 & 100.00 & & 329 & 100.00 & & \\
\hline Specific Responses if "Yes" & & & & & & \\
\hline skills & Frequency & Percentage & Rank & Frequency & Percentage & Rank & Difference \\
\hline Acquisition of entrepreneurial business) knowledge and & 57 & 71.25 & $2^{\text {nd }}$ & 254 & 77.20 & $2^{\text {nd }}$ & 5.95 \\
\hline Empowerment for self-employment & 75 & 93.75 & $1^{\text {st }}$ & 277 & 84.19 & $1^{\text {st }}$ & -9.56 \\
\hline Maximization of earnings/income via self-employment & 57 & 71.25 & $2^{\text {nd }}$ & 235 & 71.43 & $3^{\text {rd }}$ & 0.18 \\
\hline Prestige/achievement status associated with entrepreneurship & 48 & 60.00 & $4^{\text {th }}$ & 217 & 65.96 & $4^{\text {th }}$ & 5.96 \\
\hline All of the above & 40 & 50.00 & $6^{\text {th }}$ & 192 & 58.36 & $6^{\text {th }}$ & 8.36 \\
\hline Others & 3 & 3.75 & $7^{\text {th }}$ & 4 & 1.22 & $7^{\text {th }}$ & -2.53 \\
\hline Not indicated & 0 & 0.00 & $8^{\text {th }}$ & 4 & 1.22 & $7^{\text {th }}$ & 1.22 \\
\hline
\end{tabular}

Source: Choice (2008); Field Survey Result (2018)

Table 4.2.1 illustrates that all 2008 respondents affirmed that EEd was beneficial to the undergraduate recipients whereas only $95.14 \%$ believed EEd was of benefit to them in 2018 . $2.43 \%$ gave a blunt "no benefit" while another $2.43 \%$ did not indicate a position. Specific benefits identified has "empowerment for self-employment" and "acquisition of entrepreneurial (business) knowledge and skills" as ranking $1^{\text {st }}$ and $2^{\text {nd }}$ respectively for the years been compared while "maximization of earnings/income via self-employment" tied for $2^{\text {nd }}$ position in 2008 as well but ranked $3^{\text {rd }}$ in $2018.56 .25 \%$ to $71.43 \%$ of the respondents voted the remaining identified benefits as well. Not less than $50 \%$ of all respondents indicated that all benefits suffice for Entrepreneurship education.

Table 4.2.2 Responses on whether there are Obstacles to using the Knowledge and Skills Acquired in Entrepreneurship Education (while in school) after Graduation

\begin{tabular}{|c|c|c|c|c|c|c|c|}
\hline & \multicolumn{3}{|c|}{2008} & \multicolumn{3}{|c|}{2018} \\
\hline General Responses & Frequency & Percentage & Rank & Frequency & Percentage & Rank & Difference \\
\hline Yes & 62 & 77.50 & $1^{\text {st }}$ & 276 & 83.89 & $1^{\text {st }}$ & 6.39 \\
\hline No & 16 & 20.00 & $2^{\text {nd }}$ & 46 & 13.98 & $2^{\text {nd }}$ & -6.02 \\
\hline Not Indicated & 2 & 2.50 & $3^{\text {rd }}$ & 7 & 2.13 & $3^{\text {rd }}$ & -0.37 \\
\hline Total & 80 & 100.00 & & 329 & 100.00 & & \\
\hline
\end{tabular}




\begin{tabular}{|c|c|c|c|c|c|c|c|}
\hline Specific Responses if "Yes" & Frequency & Percentage & Rank & Frequency & Percentage & Rank & Difference \\
\hline Finance e.g. Lack of seed capital & 74 & 92.50 & $1^{\mathrm{st}}$ & 271 & 82.37 & $1^{\mathrm{st}}$ & -10.13 \\
\hline $\begin{array}{c}\text { Stringent government policies and legal/regulatory constraints } \\
\text { touching entrepreneurship }\end{array}$ & 48 & 60.00 & $7^{\text {th }}$ & 169 & 51.37 & $6^{\text {th }}$ & -8.63 \\
\hline $\begin{array}{l}\text { Sociological influences such as stigma attached to small business } \\
\text { ownership and/or low self esteem }\end{array}$ & 49 & 61.25 & $6^{\text {th }}$ & 157 & 47.72 & $8^{\text {th }}$ & -13.53 \\
\hline Inadequate and incompetent manpower & 54 & 67.25 & $4^{\text {th }}$ & 177 & 53.79 & $4^{\text {th }}$ & -13.49 \\
\hline Lack of market familiarity & 54 & 67.25 & $4^{\text {th }}$ & 179 & 54.41 & $3^{\text {rd }}$ & -12.84 \\
\hline $\begin{array}{l}\text { Inadequate and/or poor infrastructures e.g. Electric power } \\
\text { generation/distribution; transport/communication networks }\end{array}$ & 56 & 70.00 & $3^{\text {rd }}$ & 191 & 58.05 & $2^{\text {nd }}$ & -11.95 \\
\hline Influence/competition from foreign entrepreneurs & 45 & 56.25 & $8^{\text {th }}$ & 161 & 48.94 & $7^{\text {th }}$ & -7.31 \\
\hline Lack of technical skills & 57 & 71.25 & $2^{\text {nd }}$ & 176 & 53.50 & $5^{\text {th }}$ & -17.25 \\
\hline Opportunities for paid employment especially in blue chip firms & 45 & 56.25 & $8^{\text {th }}$ & 157 & 47.72 & $8^{\text {th }}$ & -8.53 \\
\hline All of the above & 40 & 50.00 & $10^{\text {th }}$ & 134 & 40.73 & $10^{\text {th }}$ & -9.27 \\
\hline Others & 1 & 1.25 & $12^{\text {th }}$ & 0 & 0.00 & $12^{\text {th }}$ & -1.25 \\
\hline Not indicated & 3 & 3.75 & $11^{\text {th }}$ & 12 & 3.65 & $11^{\text {th }}$ & -0.10 \\
\hline
\end{tabular}

Source: Choice (2008); Field Survey Result (2018)

Majority of respondents considered that there are indeed obstacles to using the knowledge and skills acquired in Entrepreneurship education (while in school) after graduation as disclosed in Table 4.2.2. 77.50\% attested to this position in 2008 while an increase of $6.39 \%$ made 2018 to have a higher $83.89 \%$ of those that think that there are certain obstacles to using EEd knowledge and skills. Finance e.g. lack of seed capital showed up as the most pinpointed obstacle for both the baseline year and the current year $(92.5 \%$ for 2008 and $82.37 \%$ for 2018). The differential of $-10.13 \%$ seemed to indicate that less proportion for undergraduate EEd population deemed to consider funding as an obstacle. While lack of technical skills ranked $2^{\text {nd }}$ in 2008 , inadequate and/or poor infrastructures (such as electric power generation/distribution and transport/communication networks) ranked $2^{\text {nd }}$ in 2018 but $3^{\text {rd }}$ in 2008. Lack of market familiarity was voted $3^{\text {rd }}$ obstacle in 2018. Other factors considered as obstacles ranked $4^{\text {th }}$ to $12^{\text {th }}$ in position with $47.72 \%$ to $67.25 \%$ in votes with all factors having not less that $50 \%$ vote in 2008 and $40.73 \%$ in 2018. This differential of $-9.27 \%$ indicates that less of undergraduate population of EEd in 2018 are agreeing that there are obstacles to using the business/entrepreneurial knowledge and skills acquired (while in school) after graduation or even before graduation, compare to 2008 .

Table 4.2.3 Responses on whether there are Challenges in Implementing the Curricula on Entrepreneurship Education

\begin{tabular}{|c|c|c|c|c|c|c|c|}
\hline & \multicolumn{2}{|c|}{$\mathbf{2 0 0 8}$} & \multicolumn{3}{|c|}{$\mathbf{2 0 1 8}$} \\
\hline General Response & Frequency & Percentage & Rank & Frequency & Percentage & Rank & Difference \\
\hline Yes & 73 & 91.25 & $1^{\text {st }}$ & 276 & 83.89 & $1^{\text {st }}$ & -7.36 \\
\hline No & 5 & 6.25 & $2^{\text {nd }}$ & 24 & 7.30 & $2^{\text {nd }}$ & 1.05 \\
\hline Not Indicated & 2 & 2.5 & $3^{\text {rd }}$ & 29 & 8.81 & $3^{\text {rd }}$ & 6.31 \\
\hline Total & 80 & 100.00 & & 329 & 100.00 & & \\
\hline Specific Responses if "Yes" & & & & & & & \\
\hline Inadequate government funding & Frequency & Percentage & Rank & Frequency & Percentage & Rank & Difference \\
\hline Inadequate infrastructural facilities & 58 & 72.50 & $2^{\text {nd }}$ & 233 & 70.82 & $1^{\text {st }}$ & -1.68 \\
\hline Inadequate qualified teaching staff & 60 & 75.00 & $1^{\text {st }}$ & 213 & 64.74 & $3^{\text {rd }}$ & 10.26 \\
\hline Inadequate instructional materials/equipment & 53 & 66.25 & $5^{\text {th }}$ & 202 & 61.40 & $4^{\text {th }}$ & -4.85 \\
\hline Absence of practical classes, model office and shops etc. & 58 & 68.75 & $4^{\text {th }}$ & 216 & 65.65 & $2^{\text {nd }}$ & -3.1 \\
\hline Poor attitude of students to their studies & 52 & 65.00 & $6^{\text {th }}$ & 193 & 58.66 & $6^{\text {th }}$ & -6.34 \\
\hline All of the above & 42 & 52.50 & $7^{\text {th }}$ & 169 & 51.37 & $7^{\text {th }}$ & -1.13 \\
\hline Others & 3 & 3.75 & $8^{\text {th }}$ & 2 & 0.61 & $9^{\text {th }}$ & -3.14 \\
\hline Not indicated & 3 & 3.75 & $8^{\text {th }}$ & 5 & 1.52 & $8^{\text {th }}$ & -2.23 \\
\hline
\end{tabular}

Source: Choice (2008); Field Survey Result (2018) 
On challenges bewildering the implementation of the curricula on Entrepreneurship education, Table 4.2.3 clearly tells that there are challenges. $91.25 \%$ of 2008 said "yes" and $83.89 \%$ of 2018 respondents equally voiced their affirmation. In 2018 the prominent challenge surfaced as inadequate government funding while that was second in the baseline year alongside absence of practical classes, model offices and shops. On the other hand, inadequate infrastructural facilities topped the chart of challenges in 2008 while inadequate instructional materials/equipment was the $2^{\text {nd }}$ most daunting challenge.
Interestingly, inadequate infrastructural facilities that came $3^{\text {rd }}$ in the current year was balloted as the principal challenge 10 years earlier. The differential of $10.26 \%$ seems to suggest that more infrastructures are being added to the existing ones in the countrys tertiary institutions judging by the result of the case study. On the whole the remaining challenges and indeed all the challenges were identified by a simple majority of not less than $51.37 \%$ in the years of the research. The $-1.13 \%$ differential is shows a not so significant change in the circumstances of the variables context.

Table 4.2.4 Responses on whether Entrepreneurship Education is relevant to Nigerian Economy

\begin{tabular}{|c|c|c|c|c|c|c|c|}
\hline & \multicolumn{3}{|c|}{2008} & \multicolumn{3}{|c|}{2018} & \\
\hline General Response & Frequency & Percentage & Rank & Frequency & Percentage & Rank & Difference \\
\hline Yes & 80 & 100.00 & $1^{\text {st }}$ & 289 & 87.84 & $1^{\text {st }}$ & -12.16 \\
\hline No & 0 & 0.00 & $2^{\text {nd }}$ & 11 & 3.34 & $3^{\text {rd }}$ & 3.34 \\
\hline Not Indicated & 0 & 0.00 & $2^{\text {nd }}$ & 29 & 8.82 & $2^{\text {nd }}$ & 8.82 \\
\hline Total & 80 & 100.00 & & 329 & 100.00 & & \\
\hline Specific Responses if "Yes" & Frequency & Percentage & Rank & Frequency & Percentage & Rank & Difference \\
\hline Generation of self-employment & 72 & 90.00 & $1^{\text {st }}$ & 230 & 69.91 & $2^{\text {nd }}$ & -20.09 \\
\hline Creation of job opportunities & 71 & 88.75 & $2^{\text {nd }}$ & 257 & 78.12 & $1^{\text {st }}$ & -10.63 \\
\hline $\begin{array}{l}\text { Stimulation of continuous evolution, growth and } \\
\text { development of the economy }\end{array}$ & 67 & 83.75 & $3^{\text {rd }}$ & 187 & 56.84 & $6^{\text {th }}$ & -26.91 \\
\hline Proper utilization of human potentiality and natural resources & 67 & 83.75 & $3^{\text {rd }}$ & 196 & 59.74 & $5^{\text {th }}$ & -24.01 \\
\hline $\begin{array}{l}\text { Creation, provision and improvement of/on goods, services } \\
\text { and technology }\end{array}$ & 64 & 80.00 & $5^{\text {th }}$ & 187 & 56.84 & $6^{\text {th }}$ & -23.16 \\
\hline Development of indigenous small (and medium) enterprises & 64 & 80.00 & $5^{\text {th }}$ & 199 & 60.49 & $4^{\text {th }}$ & -19.51 \\
\hline $\begin{array}{c}\text { Eradication of regional imbalances through even } \\
\text { development }\end{array}$ & 58 & 72.50 & $9^{\text {th }}$ & 178 & 54.10 & $9^{\text {th }}$ & -18.40 \\
\hline Increasing productivity & 64 & 80.00 & $5^{\text {th }}$ & 207 & 62.92 & $3^{\text {rd }}$ & -17.08 \\
\hline Higher per capital income & 61 & 76.25 & $8^{\text {th }}$ & 192 & 58.36 & $8^{\text {th }}$ & -17.89 \\
\hline All of the above & 51 & 68.75 & $10^{\text {th }}$ & 167 & 50.76 & $10^{\text {th }}$ & -17.99 \\
\hline Others & 0 & 0.00 & $11^{\text {th }}$ & 0 & 00.00 & $12^{\text {th }}$ & 00.00 \\
\hline Not indicated & 0 & 0.00 & $11^{\text {th }}$ & 20 & 06.08 & $11^{\text {th }}$ & 6.08 \\
\hline
\end{tabular}

Source: Choice (2008); Field Survey Result (2018)

Table4.2.4 gives the case-study based empirical insight into relevance of Entrepreneurship education to national economy like Nigeria. All 80 out of 80 participants in the 2008 survey gave a resounding $100 \%$ yes to EEd being relevant to Nigeria while $87.84 \%$ aligned to same positive response 10 years later i.e. in 2018. The decline of $-12.16 \%$ may not be unconnected with a growing negative perception on the standard, quality and impact of education generally, or EEd in particular, in the country. 90\% indicated in 2008 that generation of selfemployment is the chief benefit of EEd to the country followed by creation of job opportunities for others $(88.75 \%)$. These two variables of relevance switched places in 2018: creation of job opportunities, coming $1^{\text {st }}$ at $78.12 \%$ while generation of self-employment came $2^{\text {nd }}$ with $69.91 \%$. Regrettably, the declining differential of these top factors are alarming at $-20.09 \%$ and $-10.63 \%$ respectively judging by the comparative analysis of the baseline against the current year in Table 4.2.4. "Proper utilization of human potentiality and natural resources" and "Stimulation of continuous evolution, growth and development of the economy" were twin no. 3 in position for 2008 while increasing productivity came $3^{\text {rd }}$ in ranking of relevance of EEd to a national economy like Nigeria in 2018. All remaining factors polled between $54.10 \%$ and $80 \%$ by respondents to indicate how relevant they were to Nigerias economy. In all, all the factors were regarded as germane to Nigerias economy with $68.75 \%$ assertion in 2008 and $50.76 \%$ claim in 2018. Quite worrisome however is that huge differentials of between $-17.08 \%$ to $-26.91 \%$ of the factors considered as relevance to the nations economy in taking EEd in undergraduates studies for the years being compared i.e. 2008 vs. 2018. This seems to indicate a waning belief of the undergraduates and the citizens at large in the capacity of education to positively affect the nation. 
Table 4.2.5Responses on whether Unit Based Courses in Entrepreneurship Education should continue being run in Nigerias Tertiary Institutions

\begin{tabular}{|c|c|c|c|c|c|c|c|}
\hline & \multicolumn{3}{|c|}{$\mathbf{2 0 0 8}$} & \multicolumn{3}{c|}{$\mathbf{2 0 1 8}$} & Rank \\
\hline General Response & Frequency & Percentage & Rank & Frequency & Percentage & Riference \\
\hline Yes & 78 & 97.50 & $1^{\text {st }}$ & 294 & 89.36 & $1^{\text {st }}$ & -8.14 \\
\hline No & 2 & 2.50 & $2^{\text {nd }}$ & 19 & 5.78 & $2^{\text {nd }}$ & 3.28 \\
\hline Not Indicated & 0 & 0.00 & $3^{\text {rd }}$ & 16 & 4.86 & $3^{\text {rd }}$ & 4.86 \\
\hline Total & 80 & 100.00 & & 329 & 100.00 & & \\
\hline
\end{tabular}

Source: Choice (2008); Field Survey Result (2018)

Table 4.2.5 clearly revealed the need to have Entrepreneurship Education (EEd) continue being run in the nations tertiary institutions, though with a trim down in the percentage of upheld position after 10 years $(97.50$ for 2008 and 89.36 for 2018).

\section{RECOMMENDATIONS}

It is apparent the implementation of the Entrepreneurship Education (EEd) in Nigerian tertiary institutions deserves better deal than what currently holds. This study and several others point to the salient fact if the beneficiaries and the nation at large will be maximally equipped for the purposes for which EEd was introduced into undergraduate curricula and tertiary education generally, the obstacles and challenges must be properly addressed. Hence the following recommendations are made in light of the findings of this study:

1. Government, especially at Federal and State levels, and proprietors of tertiary institutions in Nigeria should make adequate funding available to see to the effective, efficient and comprehensive implementation of the curricula on EEd.

2. Government, especially at Federal and State levels, and proprietors of tertiary institutions in Nigeria should make adequate requisite infrastructures such as incubation hubs, dedicated practical labs etc. available for EEd in tertiary institutions.

3. Seed funding such as the Federal Government of Nigerias YOUWIN grants and Central bank of Nigeria (CBN) special intervention funds should be made available to encourage undergraduate start-ups for viable entrepreneurial ideas and business plans execution as an integral policy of the practice of EEd in Nigeria tertiary institutions.

4. Polytechnics and universities administrators should take networking and partnership with development organizations, international agencies, nongovernmental organizations, financial institutions, corporate bodies and other able well-meaning individuals and philanthropists seriously so as to make funding and other support schemes available for the EEd programmes in their institutions.

5. Educators should be consistently trained and retrained in the art and science of Entrepreneurship Education both theoretically and practically.
6. Governments policies and body language should be that which makes apparent her will and commitment to meaningful education that truly empowers the beneficiaries. In the same vein, enabling socioeconomic environment should be made feasible for the use of EEd or any knowledge and skills inculcated in the nations institutions.

\section{CONCLUSION}

Entrepreneurship Education at all levels, especially at undergraduate level, has the potential to put a nation on the pedestal of accelerated socio-economic transformation in growth and development and in tackling the myriads of societal problems such as unemployment, poverty, uneven development, rural-urban migration, youth unrests and other vices. If individuals, institutions and the nation Nigeria must take their place, especially in the light of a global community and have leverage for global competiveness, entrepreneurship knowledge, skills and practice at the nations tertiary institutions must receive maximum attention in terms of inputs, personal and political will, favourable policies, adequate resources especially funding, effective curricula implementation and periodic review, and partnership with relevant stakeholders that will help deal with any obstacle or challenge to Entrepreneurship Education efficacy.

\section{AUTHORS PROFILE}

Choice $\mathrm{OHC}$ is a budding academic with research interests in Entrepreneurship, Innovation Management, Human Capital Management and Development.

\section{REFERENCES}

[1] Adegoke, J. F. (2003). Development of Small and Medium Enterprises in Sustaining Economic Growth. Journal of Business and Management, 1(1), 113-124. Ede, Nigeria: School of Business Studies, Federal Polytechnic, Ede.

[2] Adiele, E. E (2010). Entrepreneurship Education a Strategy for Achieving Self-Reliance and Economic Development. Journal of Management and Enterprise Development 7(3).

[3] Agbonlahor A. A. (2016). Challenges of Entrepreneurial Education in Nigerian Universities: Towards a Repositioning for Impact. Journal of Educational and Social Research, 6(1), 208214.

[4] Agi, U. K., \& Yellowe, N. A. (2013). Management Strategies for Regenerating Secondary Education for National Development and Self-Reliance. Journal of Teacher Perspective, 7(2):1-12.

[5] Akinyemi, A. O. (1987). Effects of Government Policies on the Development of Small-Scale Industries in Nigeria. Paper presented at the National Conference on Small-Scale Industries organized by the Business and Projects Consultancy of Nigeria 
Institute of Social and Economic Research (NISER), Ibadan, February, 23-25.

[6] Aladekomo, F. O. (2004). Nigerian Educational Policy and Entrepreneurship. Journal of Social Sciences, 9(2), 75-83.

[7] Arowomole, A. M., \& Oyedokun, T. A. (2006). Entrepreneurship: Structure and Practice (Second Edition). Ibadan, Nigeria: Aseda Publishing.

[8] Awoyemi O. O., Ayobami, O. O., Azeez, M. A., and Daniel, O. W. (2005). An Appraisal of the Curriculum of Business Studies in Nigerian Polytechnic Education (A Case Study of Federal Polytechnic, Ede, Osun State of Nigeria). Unpublished National Diploma Research Project, Department of Business Administration and Management, Federal Polytechnic, Ede, Nigeria.

[9] Barker, J. (2007) Importance of Entrepreneurship. Retrieved from www.blog.yeabiz.com

[10] Choice, O. H. C. (2008). The Relevance of Entrepreneurship Education to Tertiary Institutions Students in Nigeria (A Case Study of Federal Polytechnic, Ede, Osun State of Nigeria). Unpublished Higher National Diploma Research Project, Department of Business Administration and Management, Federal Polytechnic, Ede, Nigeria.

[11] European Commission (2008) - Entrepreneurship in Higher Education, especially within Non- Business Studies. Brussels: European Commission (ISBN 978-92-79-25878-7).

[12] European Commission (2011) - Entrepreneurship Education: Enabling Teachers as a Critical Success Factor. Brussels: Entrepreneurship Unit Directorate - General Enterprise and Industry, European Commission.

[13] Federal Republic of Nigeria (1981). National Policy on Education. Lagos, Nigeria: Nigerian Educational Research and Development Council Press.

[14] Federal Republic of Nigeria (2004). National Policy on Education (4th Ed.). Lagos, Nigeria: Nigerian Educational Research and Development Council Press.

[15] Garavan, T. N., \& OCinneide, B. (1994). Entrepreneurship Education and Training: A Review and Evaluation - Part 1. Journal of European Industrial Training, 18(8), 3-12, 0309-0590. United Kingdom: MCB University Press Limited.

[16] Maina, S. (2014). The Role of Entrepreneurship Education on Job Creation Among Youths in Nigeria. International Letters of Social and Humanistic Sciences, 15 (2014), 87-96

[17] National Board for Technical Education (NBTE) (1991). Higher National Diploma in Business Administration \& Management and Public Administration - Curriculum and Course Specifications. Kaduna, Nigeria: NBTE.

[18] National Board for Technical Education (NBTE) (2004). Higher National Diploma in Business Administration and Management Curriculum and Course Specifications. Kaduna, Nigeria: NBTE.

[19] National Board for Technical Education (NBTE) (2004). National Diploma in Business Administration and Management Curriculum and Course Specifications. Kaduna, Nigeria: NBTE.

[20] National Board for Technical Education (NBTE) (2008) About UNESCO-Nigeria TVE Project in Support of Revitalizing Technical and Vocational education in Nigeria. Kaduna, Nigeria: NBTE. Retrieved from www.nbte-nigeria.org August, 2008

[21] National Planning Commission, (2004). National Economic Empowerment and Development Strategy (NEEDS), 1-80. Abuja, Nigeria: National Planning Commission.

[22] Obasanjo, O. (2003, November 5.). Challenges of Stabilizing Africa. Speech delivered at Baker Institute, Rice University, Houston Texas. Retrieved from www.nigerianvillagesquare.com

[23] Oduwaiye, R. O. (2009). Entrepreneurship Education in Nigerian Universities: Implementation and Way forward. Advances in Management, 8(1), 60-67.

[24] Okoli, N. J. (2011). History of Education: An Overview. Port Harcourt, Nigeria: University of Port Harcourt.
[25] Okoli, N. \& Allahna, J. A. (2014) Entrepreneurship Education from Pre-Colonial to Post- Independent Nigeria. Merit Research Journal of Education and Review, 2(10): 252-256, Retrieved from www.meritresearchjournals.org/er/index.htm

[26] Okojie, J. A. (2009 February 4-6). Imperative of the Federal Government Directive on the Establishment of Entrepreneurship Studies in Nigerian Universities. A Paper Presented at the 1st Conference on Effective Implementation of Federal Government Seven-Point Agenda Held at NUC, Abuja, Nigeria.

[27] Olokundun, M. A. (2017). Perceptions of Students on Entrepreneurship Education and Entrepreneurial Intentions in Selected Nigerian Universities. Unpublished doctoral thesis, Department of Business Management, College of Business and Social Sciences, Covenant University, Ota, Nigeria.

[28] Oma-Williams, O. W. (2003). Entrepreneurship Development in Nigeria: Problems, Challenges and Prospects. Nigeria Management Review- Journal of the Centre for Management Development (CMD), 14(1\&2), June-December, 1082-1093. Lagos, Nigeria: CMD.

[29] Ooi, Y. K., Selvarajah, C., \& Meyer, D. (2011). Inclination towards Entrepreneurship among University Students: An Empirical Study of Malaysian University Students. International Journal of Business and Social Science, 2(4), 206-220.

[30] Ooi, Y. K. (2008). Inclination towards Entrepreneurship among Malaysian University Students in Northern Peninsular Malaysia. Unpublished doctoral thesis, Australian Graduate School of Entrepreneurship Swinburne University of Technology.

[31] Organization for Economic Cooperation and Development (OECD) (2010). Assessment of Higher Education Learning Outcomes 2010 - 2011. OECD

[32] The Consortium for Entrepreneurship Education (2012). The State of Entrepreneurship Education 2012, Columbus, OH USA.

[33] United Nations Development Programme (2009) Human Development Report Nigeria 2008- 2009: Achieving Growth with Equity. Abuja, Nigeria: UNDP.

[34] United Nations Development Programme (2011). Human Development Report: Sustainability and Equity: A Better Future for All. United Nations Development Programme

[35] United Nations Educational Scientific and Cultural Organizations, (1991). The Role of Higher Education in Society: Quality and Pertinence. 2nd UNESCO- Non-Governmental Organizations Collective Consultation on Higher Education, Paris.

[36] United Nations Educational Scientific and Cultural Organizations, (2000). The State of Education in Nigeria. Abuja, Nigeria: UNESCO Abuja Office.

[37] United Nations Educational Scientific and Cultural Organizations (2008). Promoting Entrepreneurship Education in Secondary Schools. Final report of UNESCO Inter-Regional Seminar on Promoting Entrepreneurship Education in Secondary Schools, held in Bangkok, Thailand on 11th - 15th February, 2008

[38] United Nations Industrial Development Organizations -Nigeria, (2012). Turning Our Quantity Advantage into a Comparative Advantage. National Industrial Skill Development Programme, Abuja, Nigeria

[39] United Nations, (2010). Entrepreneurship Education, Innovation and Capacity Building In Developing Countries. United Nations Conference on Trade and Development. http://Unctad.Org/En/Docs/ Ciimem1d9_En.Pdf

[40] Visser, K. (1997, May 25-27). Education in Western Cape, South Africa. Paper presented at the Conference held in Centre for African Studies, University of Edinburgh, United Kingdom

[41] Yakubu, N. A. (2002, March, 10-16) The State of Polytechnic education in Nigeria. Paper delivered at the National Summit on Higher Education, held at ECOWAS Secretariat, Abuja, Nigeria.

[42] Zhou, M., \& Haixia X. (2012). A Review of Entrepreneurship Education for College Students in China. Adm. Sci. 2012, 2, 82-98 